\title{
Teaching Comprehension Skills using Context -Based Texts in Second Language Learning at Tertiary Level
}

\author{
Hajah Siti Akmar Abu Samah \\ WIEF-UiTM International Centre, Universiti Teknologi MARA \\ 40450 Shah Alam, Selangor. Malaysia \\ Tel: 60-3-5544-4935 E-mail: sitiakma@salam.uitm.edu.my \\ Hj. Kamaruzaman Jusoff \\ Faculty of Forestry, Universiti Putra Malaysia, \\ Serdang 43400 Selangor, Malaysia \\ Tel : 60-3-8946-7176_E-mail: kamaruz@putra.upm.edu.my
}

The research is financed by Universiti Teknologi MARA (Sponsoring information)

\begin{abstract}
Content-based reading texts play a vital role in the acquisition of knowledge and information in various fields of studies. Reading these texts at higher institution demands a great deal of effort from the students who are learners of English as a Second Language (ESL). These students who are generally school leavers, whose level or reading exposure is confined to Bahasa Malaysia-based text in their primary and secondary education, have to tackle on their own the tremendous demand of reading and comprehending the English content-based texts. These texts are derived from reference books or lecture notes, which are in English and may pose language barriers for the ESL learners. These are also ESL learners when first enter tertiary level; have met a minimum requirement of at least a credit in English as a second language at secondary school level. These reading materials pose comprehension difficulties when they are streamlined into specific field of studies. This paper attempts to look into the training of selected comprehension skills that language lecturers, particularly new ones in the teaching field, can apply the teaching skills to help learners to alleviate the comprehension challenges when reading content-based texts. This paper is also intended to assist new language lecturers who are embarking in ESL teaching of reading comprehension using content-based texts.
\end{abstract}

Keywords: Content-based, Language barriers, Tertiary, Comprehension skills

\section{Introduction}

Different faculties in the University accept different English grades (based on the national secondary school examination) as the pre-requisite in taking up programmes offered by the faculties. Some have to merit the English language subject at a pass level grade, in order to enroll while others may require the minimal non-pass level grade to be accepted into a programme. For instance, in Universiti Teknologi MARA, the pre-requirement is at least a pass in the examination mentioned above to enter the Faculty of Hotel and Tourism Management, while a non-pass grade to enroll in the Faculty of Art and Design. However, since its introduction in 1999, the Malaysian University English Test has served as the benchmark of language proficiency band that warrants students' proficiency in English for admission to all public institutions of higher education (http://www.malaysia-students.com/2007/07/malaysian-university-english-test-muet.html).

However stringent admission to the programme is with such test, in reality when these students attend the undergraduate programme, English language reading comprehension poses learning challenges to them. At the same time, English language is a course offered as a compulsory subject. Nevertheless, in helping these students to prepare them in their reading tasks of the mainstream courses, language lecturers attempt to make use of content-based texts in the reading component of the language course taught. This approach is taken as it helps the students to take on their 
mainstream courses with a more confident attitude in dealing with the nature of the text that they need to read regularly during the course of studies. Besides, this approach helps to increase the students' motivation and interest with the content courses that they will be reading for the next three or four years. At the same time, this helps them tackle the comprehension knowledge of what they will read in their course of studies.

\section{Theoretical perspective on usage of content-based texts}

Reading comprehension skills are particularly important for English language learners (ELLs). They often have problems mastering science, mathematics or social studies concepts because they cannot comprehend the texts for these subjects. ELLs at all levels of English proficiency and literacy will benefit from explicit instruction of comprehension skills along with other skills. Here is a way of thinking about the support that the ELLs need. They are required to know a lot of vocabulary and its development and teaching of comprehension skills are necessary strategies even if they are in the mainstream after some bilingual instruction, or are being pulled out for English as a Second Language. Content based text usage has been a much discussed area in the realm of English language teaching (Hutchinson \& Waters, 1992). However, considering the different views on whether to use 'composed texts' (Allen \& Widdowson, 1974) or to use 'authentic text', the fundamental objective of using content-based text has an advantage discussed above. In addition the use of content-based materials is a teaching-learning process for the language lecturers as well as for the ESL students.

Using content-based texts is preferable as these texts are streamlined with the kind of texts used by the students in their field of studies. These texts are easily accessible as language lecturers do not have to manage the aspects of the texts which can be quite complicated. Using content-based texts can save time preparing for language lessons. On the contrary, using materials which are specially written or adapted by language lecturers pose the fact that the use of syntax and lexis is too contrived. Besides, the linguistic features have to be made peculiar to the related information of a particular field. Simultaneously, distortion on the information structure of the texts can lead to further confusion. In their proposal Hutchinson \& Waters (1992) have suggested feasible teaching approaches that can assist ESL learners in dealing with the use of content-based texts in language learning. The approaches help the learners realize that by using language strategies they will be able to acquire knowledge with minimal hindrance. The teaching of the language strategies, particularly in teaching certain language items, sentences from the content-based texts can be explicitly taught using specialized field related texts.

Reading is defined as a transaction between the reader and the text in a specific context, and that it can result in the creation of a new text in the mind of the reader (Irwin, 1991). At the same time too, reading has drawn upon the commonly accepted definition as "the ability to utilize the conceptual and linguistic knowledge a reader has and simultaneously the ability to increase its depth and scope by constructing more advanced mental structures" during which a person is engaged in the reading process. Its importance is so indispensable that this skill forms the mechanics of acquiring knowledge from as early as beginning of learning. For that, for beginning reading, parents stress so much importance in teaching their babies to learn how to read, young learners are taught reading the day they step into schools and adult learners are provided with lists of references of reading materials for them to read even before their courses begin. In fact, to create an information-rich society today, people need to master this skill effectively.

During the reading process, the reader uses his existing knowledge and strategies to interact with the texts in order to extract meaning from the text. For this, many researchers have agreed that reading, to a certain extent, is a dynamic process. It has been extensively researched and as stated in Cantoni-Harvey (1987) that language component has drawn upon the commonly accepted definition as "the ability to utilize the conceptual and linguistic knowledge a reader has and simultaneously the ability to increase its depth and scope by constructing more advanced mental structures" (Cantoni-Harvey, 1987) during which a person is engaged in the reading process.

When reading is considered successful, a student whom we considered as 'good at comprehension' is able to read accurately and efficiently. Subsequently, the student is able to get the optimal information from a text with the minimum of understanding. Secondly, the success of reading can be illustrated by his ability to show his understanding by re-expressing the content of the text, for example, by writing sentences or paragraphs in answering to the questions, picking the accurate options as the answer from a multiple-choice question or by summarizing the text (Swan, 1986).

However, in a real classroom, improving reading comprehension measures are documented by research as found in a study by Palinscar and Brown (1984), the focus shifted to using combinations of strategies to facilitate text comprehension. In their 1984 study of "reciprocal teaching" of comprehension by Palinscar and Brown (1984), it involves the gradual release of responsibility for carrying out a strategy to the readers. It combines teacher modeling and student practice on four cognitive strategies: prediction, clarifying, summarizing, and question generation. Students who received this instruction showed marked improvement on a number of comprehension measures. In the process of reading and understanding content-based text, lecturer has to be fully prepared to teach comprehension in the classroom effectively. (http://www.doe.in.gov/lmmp/pdf/content_area_texts.pdf). This is substantiated by two approaches in studies made by Duffy and Roehler (1987) direct explanation model and Rachel Brown, Michael Pressley, and colleagues' 1996 transactional instruction approach (Block and Pressley, 2002). Direct explanation emphasizes 
teacher-directed problem solving, whereas transactional instruction employs teacher-directed actions with interactive exchanges with students in classrooms. From these studies indication has shown positive results in student's level of understanding when language teachers are given proper guidance in teaching reading and comprehension.

Again, in 1993, after a five-year study of teaching teachers to implement reading comprehension teaching, Gerald G. Duffy, a developer of the direct-instruction approach to cognitive strategy instruction, concluded that teaching students to acquire and use strategies requires a fundamental "change in how teacher educators and staff developers work with teachers and what they count as important about learning to be a teacher". It is therefore necessary that to improve readers' comprehension performance, language teachers have to be shown the 'way' to teach effectively. In the year 2000, in her address to teachers, Carol Minnick Santa, President of the International Reading Association, noted that "teaching [comprehension] is a lot harder and more abstract than teaching phonemic awareness or language structures. Moreover, effective comprehension instruction ... demands extensive teacher knowledge." Language lecturers at novice stage needs extensive opportunity to acquire the teaching skills and this paper shows the comprehension skills which are found to be necessary in acquiring comprehension from reading a text.

Teaching comprehension of text successfully requires the ESL lecturers to be strategic in creating the lesson that will make comprehension a manageable task after reading. In so doing, and doing them appropriately, they are required to teach until the ESL learners' comprehension problems are resolved. The language lecturers facilitate the learning strategies of ESL learners apart from adjusting, modifying and testing using texts. In its initial preparation, the lecturer needs to create awareness of comprehension such as to find out what the paragraph or the gist of the paragraph is about.

\section{Enhancing Reading Comprehension Using Content-based Text}

The following is a content-based text extracted from the Lecture FHK 3403: Forest Engineering given to undergraduate of English as a second language level to read and comprehend. In the attempt to comprehend the content English language learning is provided for the learners to facilitate reading and comprehension in order to enhance acquisition of knowledge and information effectively. Read the text below and strategies comprehension of the texts through recognizing the instruction given. These tasks attempt to create comprehension of reading the content-based text and by providing answers to the instruction of each item listed below helps create comprehension awareness of the text further.

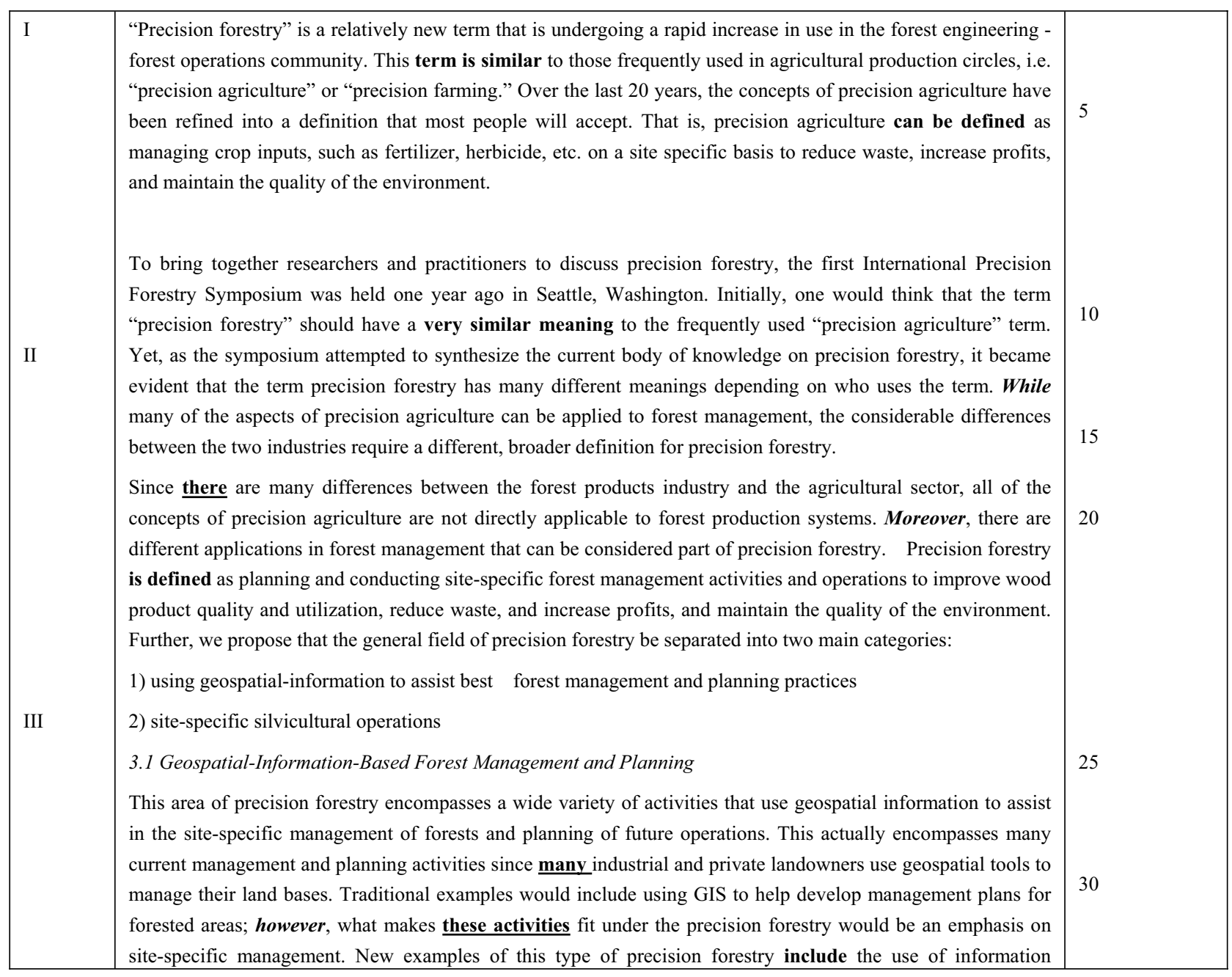




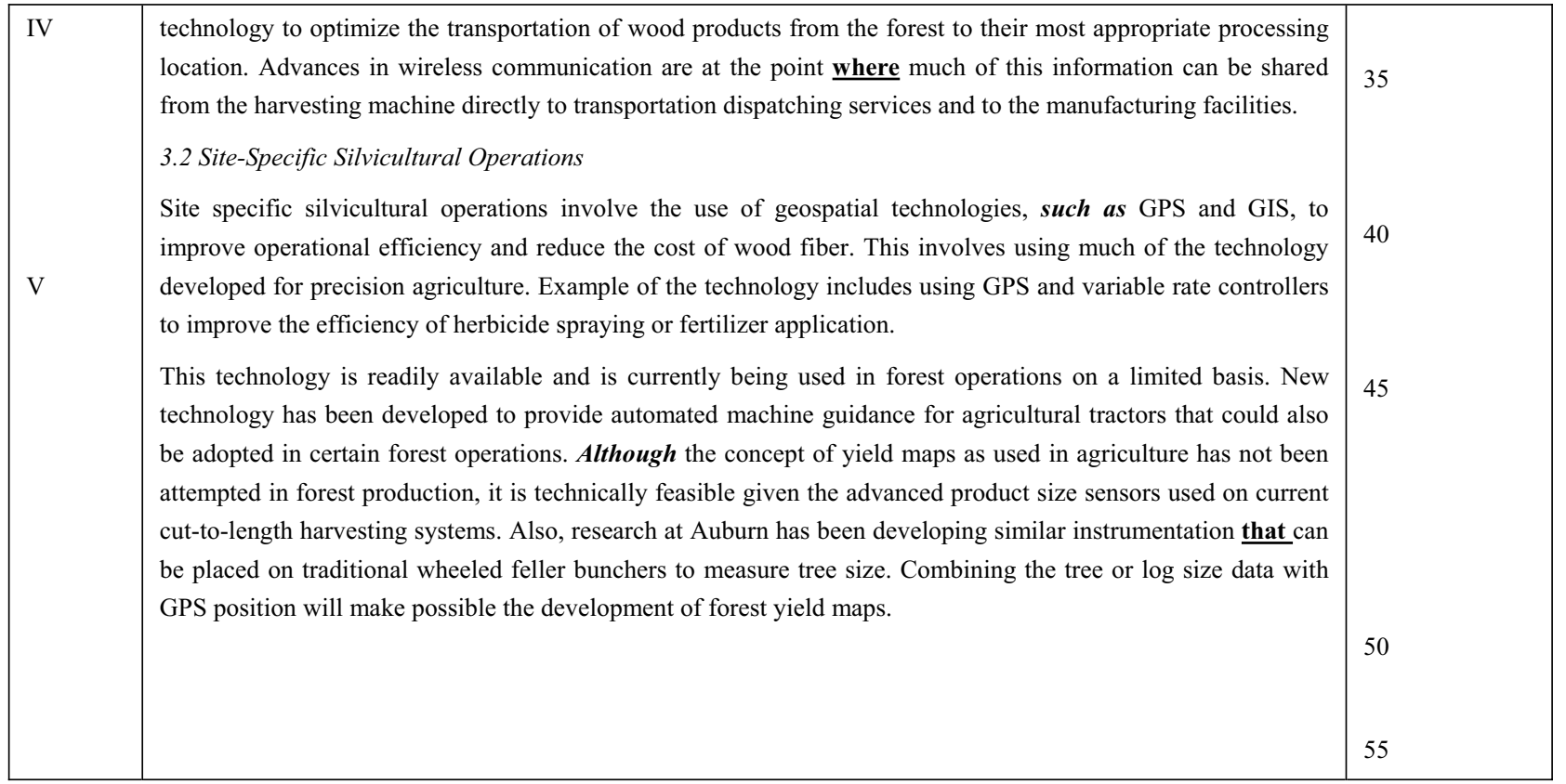

Sample Content-based Text Adapted From: LECTURE FHK 3403: FOREST ENGINEERING PRECISION FORESTRY: POSSIBLE TOOL FOR SUSTAINABLE FOREST MANAGEMENT IN MALAYSIA Instructor: Hj.Kamaruzaman Jusoff (HjKJ) Credit Hours: $3(2+1)$ Venue: Room 143, Forestry Building Semester: 1 2007/8

To assist the ESLs deal with the above text, the text analysed with the language items that pose elements of comprehension using the following comprehension skills:

\begin{tabular}{|c|c|c|}
\hline & Comprehension Skills & Instructions and Activities \\
\hline 1. & Meaning From Contextual Clues & 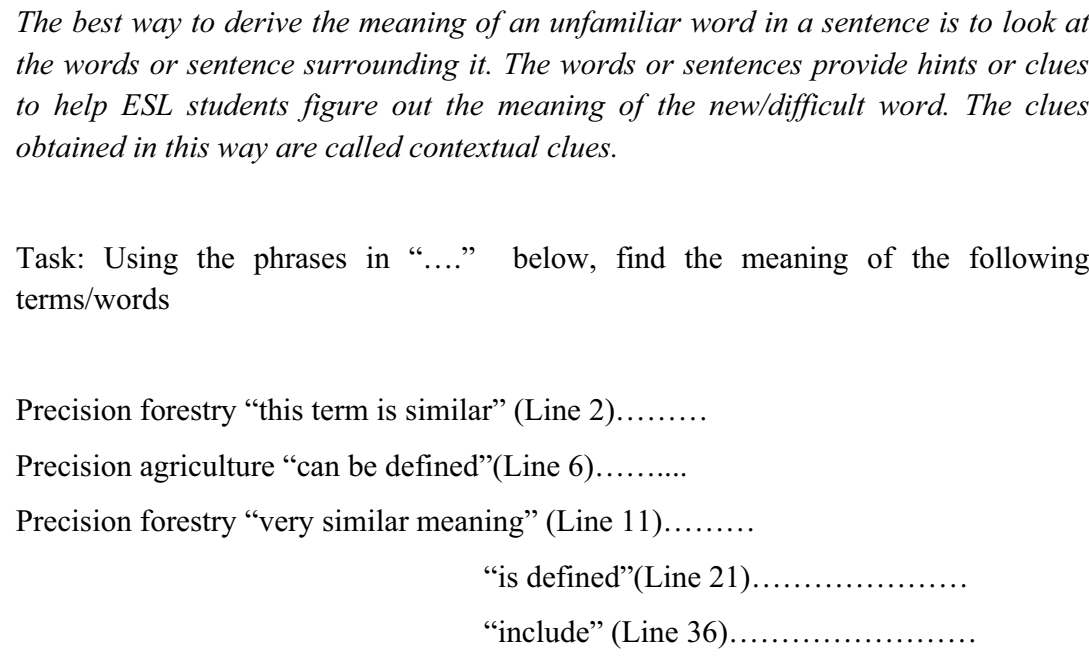 \\
\hline 2. & Discourse Markers & $\begin{array}{l}\text { Knowing what discourse markers are enables the learners to understand and follow } \\
\text { how the writer has organized or fitted his ideas together. In this way, comprehension } \\
\text { of the text becomes easier. } \\
\text { Task: The following words are used to join two ideas from the text. Write what the } \\
\text { ideas are: } \\
\ldots \ldots \ldots \ldots \ldots \text { while (Line } 15) \ldots \ldots \ldots \ldots \ldots \ldots \\
\ldots \ldots \ldots \ldots \ldots \ldots\end{array}$ \\
\hline 3. & References & Reference words are words which replace other words or phrases. There are two \\
\hline
\end{tabular}




\begin{tabular}{|c|c|c|}
\hline & & $\begin{array}{l}\text { types of references: } \\
\text { - } \quad \text { Words which refer to information or ideas mentioned before the reference word } \\
\text { - Words which refer to information or ideas mentioned after the reference } \\
\text { Task: These words in the text refer to: } \\
\text { There (para 3) refers to ...... } \\
\text { Many (para 4) refers to ....... } \\
\text { Where (para 4) refers to ...... } \\
\text { These activities (para ) refers to ........ } \\
\text { That (para ) refers to ......... }\end{array}$ \\
\hline 4. & Main Ideas & $\begin{array}{l}\text { The main idea of a paragraph or text is what the text or paragraph is generally } \\
\text { about. It can be identified by asking two important questions: } \\
\text { - What is the topic of the paragraph/text? } \\
\text { - What does the writer want you to know about the topic? } \\
\text { Task: Write the main idea of Paragraph } 4\end{array}$ \\
\hline 5. & Topic Sentence & $\begin{array}{l}\text { Sometimes one sentence within the paragraph tells the reader exactly what the } \\
\text { paragraph is about. This sentence is often called a topic sentence. It may appear at } \\
\text { the beginning, the middle or at the end of the paragraphs. } \\
\text { Task: Identify the topic sentence of paragraph } 4\end{array}$ \\
\hline 6. & Supporting details & $\begin{array}{l}\text { Supporting details are the explanations, reasons or examples that support the topic } \\
\text { sentence of the paragraph. } \\
\text { Task: Write three supporting details of Paragraph } 4 \\
1 . \\
\text { 2. } \\
\text { 3. }\end{array}$ \\
\hline
\end{tabular}

\section{Conclusion}

The position of the language lecturer servicing the specialized schools in teaching can commensurate to that of the ESP teachers as suggested by Hutchinson and Waters (1992) as being "all too often reluctant dwellers in a strange and uncharted land:" They may face language teaching challenges all too often but with constant guidance from senior lecturers who are more experience need to be generated so that new language lecturers continue to upgrade teaching. The framework suggested above acts as guideline for lecturers and students as well, to have better awareness of comprehending texts that are read.

Conducting proper orientation to the content subject knowledge helps new language lecturer to acquire knowledge and information of the content material better. Every faculty needs to provide sufficient information or made available reading materials for language lecturers to be exposed to. This is however not recommending that the language lecturers learn subject knowledge but being aware of the content-based text is a useful guide to plan lessons and to teach ESL students the appropriate technique to enhance comprehension.

For continuous improvement, it is highly recommended that collaboration between language lecturers and content lecturers be further enhanced as synergizing efforts put by both parties can contribute to effective use of content based materials for language learning experiences. These efforts help the ESL students to acquire information of the course area and cope with the language demands that are met simultaneously.

\section{References}

Allen, J.P.B. \& Widdowson, H.G. (1974). Teaching the Communicative Use of English International Review of Applied Linguistics in Language Teaching XII, 1-21 January 1974.

Anderson, N. (1999). Exploring second language reading: Issues and strategies.Boston, MA: Heinle \& Heinle. 
Block, C.C. \& Pressley, M. (2002). Comprehension Instruction: Research-based Best Practices Language Arts and Discipline Guilford Press UK.

Cantoni-Harvey, G. (1987). Content-Area Language Instruction Approaches and Strategies Addison-Wesley Publishing Company USA .

Chamot, A. U. \& O’Malley, J. M. (1994). The CALLA handbook. Reading, MA: Addison-Wesley.

Durkin, D. (2004). Teaching them to read $6^{\text {th }}$ Edition Allyn \& Bacon USA.

Grellet, F. (1981). Developing Reading Skills A Practical Guide to Reading Comprehension Exercises Cambridge University Press, Cambridge .

Hudson, T. (1984). A Content Comprehension Approach to Reading English for Science and Technology. TESOL Quarterly. p.77.

Hutchinson, T. \& Waters, A. (1987). English for Specific Purposes: A learning-centered approach. Cambridge: Cambridge University Press.

Irwin, J. W. (1993) Teaching Reading Comprehension Purposes. Allyn and Bacon, USA

Kamaruzaman Jusoff . (2007). Forest Engineering Lecture Notes. Credit Hours: $3(2+1)$ Venue: Room 143, Forestry Building, Universiti Putra Malaysia, Serdang, Selangor, Malaysia.

Lee King Siong. (1994). Problems of Malay Students Academic Text in English A Dissertation of Master of Modern Language. University of Malaya, Kuala Lumpur.

McConkie, G. (1973). Experimental Manipulation of Reading Strategies. Journal of Educational Psychology, 65,1, 1-8, August 1973.

McKay, S.L. (1992). Teaching English Oversea: An Introduction. Oxford University Press, UK.

Palinscar, A.S. \& Brown A.L. (1984) Reciprocal Teaching of Comprehension Fostering of Comprehension Monitoring Activities informaworld.com.

Pearson, P.D. \& Gallagher M.C. (1983). The instruction of reading comprehension. Contemporary Educational Psychology, 8, 317-344.

Pressley, M. (2001). Comprehension instruction: What makes sense now, what might make sense soon. Reading online, $5(2)$.

Swan, M. (1986). Inside Meaning: Proficiency Reading Comprehension Cambridge, Cambridge University Press. http://iteslj.org/Articles/Davies-CBI.html.

http://www.doe.in.gov/lmmp/pdf/content_area_texts.pdf.

http://www.literacymatters.org/content/text/intro.htm.

http://www.smithsonianmag.com/people-places/10023991.html.

http://edhelper.com/language/Reading_Skills.htm.

http://www.malaysia-students.com/2007/07/malaysian-university-english-test-muet.html.

http://www.jstor.org/pss/1170735.

http://mindpower.smartads.info/education-and-learning/article.php?art=7820.

http://iteslj.org/Articles/Gatehouse-ESP.html Key Issues in English for Specific Purposes (ESP) Curriculum Development Kristen Gatehouse khoey [at] khae-service.com www.khae-service.com. 